\title{
HARMONISASI HUKUM KONTRAK DAN DAMPAKNYA PADA HUKUM KONTRAK INDONESIA
}

\author{
Samuel Hutabarat \\ email: samuelhut@yahoo.com
}

\begin{abstract}
International commercial contracts are contracts closed by parties coming from different countries or made under "foreign" legal systems. Parties may have different understandings about how to read the contract and therefore it is of importance to include in the contract a provision on settlement of disputes containing choice of forum and/or choice of law. A different way to prevent conflicts and disputes stemming from the interpretation and implementation of international commercial contracts is by way of harmonization of national contract laws. Indonesia as an active member of the international (commercial) community should take the initiative to do so. In other words, revision of the existing Indonesian contract law is much needed.
\end{abstract}

Keywords:

contract, harmonize, international commercial contract

\begin{abstract}
Abstrak
Kontrak komersial internasional adalah kontrak yang ditutup para pihak yang berasal dari Negara berbeda atau tunduk pada sistem hukum berbeda. Karena ketentuan dalam kontrak dapat ditafsir berbeda oleh para pihak, maka kontrak demikian itu harus memuat ketentuan perihal penyelesaian sengketa yang sekaligus memuat pilihan hukum atau pilihan forum penyelesaian sengketa. Satu cara lain yang tersedia untuk mencegah munculnya sengketa dan konflik hukum dari kontrak-kontrak komersial internasional adalah melalui penyelarasan hukum kontrak nasional Negara-negara. Indonesia sebagai anggota aktif masyarakat komersial internasional harus segera melakukan prakarsa untuk itu. Dengan kata lain, hukum kontrak Indonesia harus segera direvisi.
\end{abstract}

Kata kunci:

kontrak, harmonisasi, kontrak komersial internasional

\section{Pendahuluan}

Perkembangan ekonomi global dan integrasi ekonomi serta tingginya transaksi perdagangan yang secara khusus terjadi pada wilayah regional ASEAN, telah memberikan dampak pertumbuhan ekonomi dari masing-masing Negara ASEAN. Tingginya transaksi perdagangan itu memerlukan aturan-aturan yang dapat menunjang transaksi perdagangan antar Negara anggota ASEAN. Aturan domestik dari masing-masing Negara tentunya menjadi acuan dari setiap pelaku bisnis yang akan melakukan transaksi perdagangan di Negara yang berbeda. Tentunya tak terelakkan bahwa aturan hukum nasional yang relevan akan 
diselaraskan dengan kebutuhan dan perkembangan dari pesatnya transaksi perdagangan internasional. Selain hukum domestik masing masing Negara yang diterbitkan oleh pemerintahan dari suatu Negara, aturan lainnya yang menjadi acuan para pihak pelaku bisnis adalah kontrak. Hukum kontrak Negara-negara ASEAN untuk sebahagian besar dipengaruhi oleh baik hukum Barat dalam bentuk common law ataupun civil law.

Satu instrumen terpenting dalam transaksi perdagangan internasional adalah kontrak. Kontrak (dagang) inilah yang merupakan jembatan penghubung yang memuat pengaturan aktivitas komersial ataupun aktivitas bisnis ${ }^{1}$. Dengan kata lain, perlu adanya kontrak dagang internasional (international commercial contracts) ${ }^{2}$ yang berfungsi sebagai acuan perilaku yang memuat hak dan kewajiban para pihak dalam kontrak. Kontrak-kontrak dagang internasional ini dalam dirinya sendiri bersifat lintas batas Negara. Satu pendapat menyatakan bahwa kontrak internasional adalah kontrak yang di dalamnya terdapat unsur dua Negara atau lebih, dan kontrak tersebut dibuat antara Negara dengan Negara, Negara dengan pihak swasta, atau di antara pihak swasta ${ }^{3}$. Berbeda dengan itu, Sudargo Gautama menyebut suatu kontrak sebagai kontrak internasional karena

1 Ricardo Simanjuntak, Asas-asas Utama Hukum Kontrak dalam Kontrak Dagang Internasional: sebuah Tinjauan Hukum, Jurnal Hukum Bisnis Vol 27 No. 4 tahun 2008, hlm., 14.

2 Penulis menggunakan istilah kontrak dagang internasional bukan perjanjian internasional, karena perjanjian internasional adalah perjanjian yang diadakan antara anggota masyarakat bangsa-bangsa dan bertujuan untuk mengakibatkan akibat-akibat hukum tertentu. Di dalam Teori Hukum Internasional, Perjanjian Internasional dibedakan ke dalam 2 (dua) golongan, yaitu: 1. law making treaties dan 2. Treaty contracts. Law making treaties merupakan perjanjian internasional yang mengandung kaidah-kaidah hukum yang dapat berlaku secara universal bagi anggota masyarakat bangsa-bangsa, sehingga dengan demikian dapat dikategorikan sebagai perjanjian internasional yang berfungsi sebagai sumber langsung hukum internasional. Treaty contracts adalah perjanjian internasional yang mengatur hubungan-hubungan atau persoalanpersoalan khusus antara pihak-pihak yang mengadakan perjanjian saja. Treaty contracts tidak secara langsung menjadi sumber hukum internasional. Nani Suryani, Harmonisasi Hukum Ekonomi Negara-negara ASEAN dalam menghadapi Pasar Bebas 2010, Jurnal Ilmu Hukum, Wacana ParamartaVol VIII, No.1 Mei 2009 Hlm. 42. Mochtar Kusumaatmadja, Pengantar Hukum Internasional, Bandung, Bina Cipta, $1978 \mathrm{Hlm}$. 109,115 dan 115. JG Starke, Introduction to International Law, London, Butterworths, 1984, hlm., 40-44.

3 Wilis L.M Reese, "The Law Governing International Contracts," dalam: Hans Smit, et. al., International Contracts, New York: Mathew Bender, 1981, hlm., 4. 
adanya unsur-unsur asing termuat di dalamnya (foreign element) ${ }^{4}$. Secara teoritis, unsur asing yang ada dalam suatu kontrak internasional adalah ${ }^{5}$ :

a. Kebangsaan yang berbeda;

b. Para pihak memiliki domisili hukum yang berbeda;

c. Hukum yang dipilih adalah hukum asing;

d. Pelaksanaan kontrak di luar negeri;

e. Penyelesaian sengketa kontrak di luar negeri;

f. Kontrak tersebut ditandatangani di luar negeri;

g. Obyek kontrak di luar negeri;

h. Bahasa yang digunakan dalam kontrak adalah bahasa asing;

i. Digunakannya mata uang asing dalam kontrak tersebut.

Terlepas dari persoalan definisi hukum kontrak internasional, perlu dicermati bahwa hukum kontrak nasional masing-masing negara pada dasarnya sangat beragam. Perbedaan sistem hukum di masing-masing Negara tersebut menjadi tidak kondusif bagi aktivitas dunia bisnis internasional. ${ }^{6}$ Perbedaan sistem hukum nasional serta ketentuan-ketentuan hukum kontrak masing-masing Negara membuka peluang terjadinya konflik dan sengketa. Selain itu perbedaan hukum nasional yang menjadi acuan normatif dari para pelaku transaksi perdagangan internasional juga dapat menimbulkan keragu-raguan dan ketidapastian bagi pihak asing. Bahkan bisa menimbulkan kekecewaan tersendiri karena apa yang pada awalnya dipahami sebagai hak dan kewajiban masingmasing pihak ternyata harus ditafsirkan berbeda dalam sistem hukum nasional yang ada. ${ }^{7}$

Perbedaan aturan (hukum kontrak) di masing-masing Negara berpeluang besar menghambat transaksi bisnis internasional yang menghendaki kecepatan

\footnotetext{
${ }^{4}$ Sudargo Gautama, Kontrak Dagang Internasional, Bandung: Alumni, 1976, hlm., 7.

${ }^{5}$ Huala Adolf, Dasar-dasar Hukum Kontrak Internasional, cet. ke-2, Bandung, Refika Aditama, 2008, hlm. 29.

6 Supra no 4 , hlm., 7.

7 Sudargo Gautama, Hukum Perdata dan Dagang Internasional, Alumni, Bandung, 1980, hlm. 237.
} 
dan kepastian. ${ }^{8}$ Padahal, perdagangan internasional telah berkembang menjadi kebutuhan mendasar untuk menjaga kelangsungan ekonomi dunia yang dicirikan interdependensi ekonomi. ${ }^{9}$ Dalam lingkup regional ASEAN, perdagangan internasional yang terjadi adalah antara warganegara dari sesama Negara-negara anggota ASEAN atau dari luarnya. Masalah selanjutnya adalah, meskipun bentuk kontrak internasional telah berkembang, namun aturan-aturan hukum yang terumuskan secara formal mengenai kontrak internasional belum cukup berkembang. Artinya ada kebutuhan untuk menyesuaikan hukum nasional masing-masing Negara terutama di bidang hukum kontrak, salah satunya dengan cara harmonisasi.

Kendati begitu ada perbedaan pandangan di antara para ahli hukum tentang kemanfaatan harmonisasi hukum kontrak nasional. Beberapa ahli hukum kontrak, sekalipun sudah dapat melihat manfaat yang relevan dari harmonisasi hukum kontrak, tetap ragu tentang itu. Padahal harmonisasi terbukti telah memberikan manfaat dalam pengembangan dan modernisasi hukum nasional. Harmonisasi pada akhirnya mendukung dan bukan menjadi menghambat perdagangan internasional. Hal serupa dapat dikatakan tentang hukum nasional Indonesia yang tumbuh kembang di tengah kawasan regional ASEAN.

Dimaksudkan di sini dengan harmonisasi adalah penyelarasan aturanaturan hukum yang bersifat global atau regional dengan aturan hukum yang bersifat domestik. Banyak pendapat dan diskusi yang dibuat tentang pentingnya harmonisasi dalam rangka perdagangan internasional dan ada banyak organisasi, baik internasional dan regional, antar pemerintahan dan swasta, yang bekerja keras berupaya mewujudkan harmonisasi tersebut. Dalam konteks itu, secara konkrit telah diupayakan penyelarasan aturan-aturan hukum nasional di bidang bea cukai, impor dan ekspor, dan secara khusus harmonisasi bidang hukum kontrak nasional. Mengapa hukum kontrak nasional penting untuk diharmonisasi?

\footnotetext{
8 Id.

${ }^{9}$ William F. Fox, International commercial Agreement A Primer on Drafting, Negotiation and Resolving Disputes, Third Edition, The Hague, Kluwer Law International, 1998, hlm., 1.
} 
Alasannya adalah karena perbedaan-perbedaan yang ada dalam masing-masing hukum kontrak nasional justru dapat menjadi hambatan untuk perdagangan internasional.

Salah satu upaya yang efektif dalam harmonisasi hukum kontrak internasional dilakukan oleh organisasi internasional seperti International Institute for the Unification of Private Law (UNIDROIT). Harmonisasi adalah alat yang berguna dalam memberikan pilihan netral hukum dalam menentukan keabsahan suatu kontrak dan melaksanakan suatu kontrak serta menyelesaikan suatu sengketa. International Institute for the Unification of Private Law (UNIDROIT) telah mengeluarkan UNIDROIT Principles of International Commercial Contracts (UPICC) atau yang biasa dikenal dengan Prinsip UNIDROIT. Prinsip UNIDROIT ini pertama kali diterbitkan pada 1994, kemudian dilakukan revisi pada 2004, dan kemudian sampai saat ini revisi terakhir yang dilakukan adalah pada 2010.10

Selain dari UNIDROIT Principles, konvensi PBB lainnya yang memberikan pengaruh besar dalam rangka harmonisasi hukum kontrak yaitu United Nations Convention on contracts for International Sale of Goods (CISG 1980). Konvensi ini mengenai kontrak jual beli barang secara internasional yang disahkan di kota Wina pada 1980. CISG 1980 dipandang sebagai suatu perjanjian internasional pertama yang sifatnya komprehensif di bidang kontrak yang dibuat oleh Negaranegara di dunia sejak Perdang Dunia II. ${ }^{11}$ Latar belakang hadirnya CISG 1980 diantaranya karena meningkatnya transaksi perdagangan internasional yang memerlukan suatu konvensi yang menyeluruh ${ }^{12}$, adanya berbagai sistem hukum yang berbeda yang mengatur kontrak perdagangan yang dipandang tidak begitu kondusif bagi perdagangan internasional serta kelemahan 2 (dua) Konvensi Den

\footnotetext{
10 International Institute for The Unification of Private Law, International Principles of Commercial Contracts, Roma, 2010, Introduction.

${ }^{11}$ Kenneth C, Randall dan John E Norris, A New Paradigm for international Business Transaction 71 U Wash L Q 606 (1993) Pada Huala Adof, Instrumen-instrumen tentang kontrak Internasional, Keni Media, Bandung, 2011, hlm. 125.

12 Supra no 7, hlm., 233.
} 
Haag 1964 yaitu Konvensi tentang hukum yang berlaku terhadap jual-beli internasional (The Convention Relating to a Uniform Law on The International sale of Goods (ULIS)) dan Konvensi tentang Pembentukan kontrak jual beli internasional (The Convention Relating to a Uniform Law on The Formation of Contract for the International Sale of Goods). Kedua konvensi ini kurang disambut baik oleh banyak pengamat hukum, karena ketentuan-ketentuan yang terkandung dalam kedua konvensi ini dipandang semata-mata mencerminkan tradisi-tradisi hukum dan ekonomi yang berlaku pada Negara-negara Eropa Kontinental. ${ }^{13}$

UNIDROIT Principles memberikan model pengaturan bagaimana menyelesaikan sengketa terkait kontrak dagang internasional. Seperti yang telah ditunjukkan dalam beberapa kasus dimana pengadilan telah menerapkan The International Institute for the Unification of Private Law (UNIDROIT Principles). Prinsip UNIDROIT atau berdasarkan United Nations Convention on contracts for International Sale of Goods (CISG 1980) ${ }^{14}$ baik sebagai sumber prinsip umum hukum dan sebagai instrument, berfungsi sebagai acuan untuk menafsirkan dan melengkapi hukum kontrak nasional. Selain itu, beranjak dari prinsip-prinsip UNIDROIT yang sama, maka perbedaan suatu sistem hukum dengan sistem hukum lain tidak lagi menjadi rintangan atau kendala bagi para pihak dalam melakukan transaksi perdagangan internasional. ${ }^{15}$

Penggunaan UNIDROIT Principles dan CISG 1980 dalam menyelesaikan sengketa yang muncul dari kontrak-kontrak dagang internasional sebagaimana diilustrasikan di atas merupakan bukti nyata bahwa keduanya sebagai hukum kontrak modern yang netral mampu menjembatani perbedaan aturan hukum kontrak dari Negara-negara yang bersengketa. Hal ini sesuai dengan tujuan dari

${ }^{13}$ Supra no 5, hlm., 126.

14 Lihat ICC Awards No. 8502 of 1996, ICC International Court of Arbitration Bulletin 72-74. Concerning a contract for the supply of rice entered into between a Vietnamese exporter and French and Dutch buyers. The contract did not contain any choice of law clause. The arbitral Tribunal decided to base its wards on trade usage and generally accepted principles of international trade and to refer in particular to The 1980 Vienna Convention on Contracts for International Sale of Goods (CISG 1980) or to the Principles of International Commercial Contract Enacted by UNIDROIT as evidencing admitted practices under international trade law.

15 Supra no 5, hlm., 7. 
UNIDROIT Principle yang dimaktubkan di bagian pembukaannya. Baik CISG 1980 ataupun UNIDROIT Principle berupaya agar terciptanya suatu harmonisasi hukum atau aturan-aturan dalam perdagangan internasional, sehingga dapat menjadi jalan ke luar, jika terjadi masalah dalam aturan terkait dengan pelaksanaan kontrak perdagangan internasional. Perbedaan utama dua instrumen ini tampak dari judul kedua konvensi ini. UNIDROIT Principle memperlihatkan bahwa obyek pengaturan tidak secara tegas mencantumkan jual-beli internasional dan berupaya membuat acuan umum hukum kontrak internasional untuk transaksi yang tidak terbatas pada jual-beli barang internasional. ${ }^{16}$

Hukum kontrak Indonesia pada awalnya sangat dipengaruhi oleh hukum adat (Adat Law), ${ }^{17}$ yaitu aturan-aturan yang berkembang sesuai dengan adatistiadat dari masing-masing suku yang ada di Indonesia yang mengatur kehidupan mereka sehari-hari. Salah satu ciri khas dari kontrak berdasarkan hukum adat, yaitu suatu kontrak menjadi mengikat pada saat obyek dari kontrak sudah diserahkan dan diterima. Hal ini berbeda dengan hukum Eropa. Kontrak menjadi mengikat pada saat penerimaan, baik dilakukan hanya secara lisan atau tertulis tanpa panjer sebagai suatu tanda penerimaan. ${ }^{18}$ Pemerintah kolonial Belanda kemudian memberlakukan dua kitab Undang-undang (Burgerlijke Wetboek dan Wetboek van Koophandel), berdasarkan asas konkordansi, dan keduanya ini sampai sekarang besar pengaruhnya terhadap perkembangan hukum kontrak Indonesia. KUHPerdata ini diberlakukan di Hindia Belanda berdasarkan maklumat 30 April 1847 (Stb. 1847 nomor 23), dan di Indonesia kemudian diundangkan melalui Stb. 1848 (mulai berlaku 1 Januari 1848).

Saat ini, sebagai konsekuensi dari sistem terbuka (dari buku III KUHPerdata) di Indonesia, Hukum Kontrak memberikan kesempatan kepada semua orang untuk bebas membuat kontrak, bahkan kontrak asing, termasuk

16 Id.

17 Lihat pendapat Van Vollenhoven yang memberikan ciri khusus dalam hukum adat, yaitu Komunal, Tunai dan Konkrit.

18 Sunaryati Hartono, Setiawan, Taryana Sunandar, The Indonesia Law on Contracts, Institute of Developing Economies (IDE JETRO), Japan, 2001, hlm. 3-4. 
yang terkait dengan investasi asing atau transaksi perdagangan internasional. Beranjak dari kenyataan ini, maka di Indonesia-pun dapat ditemui perbedaan antara kontrak yang dibuat berdasarkan hukum kontrak Indonesia dan kontrak asing. Juga dalam hal ini kiranya ada kebutuhan untuk melakukan harmonisasi hukum kontrak di Indonesia dalam konteks pengembangan transaksi-transaksi perdagangan internasional.

\section{UNIDROIT Principle, CISG 1980 Dan Kitab Undang-Undang Hukum Perdata}

Sebagaimana sudah diindikasikan di atas dapat dikatakan bahwa dewasa ini rezim yang paling penting untuk kontrak perdagangan internasional adalah The United Nations Convention on Contracts for the International Sale of Goods 1980 (CISG 1980) dan The Unidroit Principles for International Commercial Contracts (UNIDROIT Principles) ${ }^{19}$. CISG 1980 dan UNIDROIT Principles berlaku untuk semua jenis kontrak komersial, namun keduanya adalah dua rezim yang berbeda dalam proses pembentukannya. CISG 1980 adalah konvensi internasional antara negara-negara berdaulat, sementara UNIDROIT Principles merupakan seperangkat aturan yang dikodifikasikan, dikembangkan dan direkomendasikan oleh International Institute for Unification of Private Law (UNDROIT), yang merupakan organisasi antar pemerintah dari 63 anggota negara ${ }^{20}$ sebagai model hukum dan hukum yang berlaku untuk anggota pada khususnya dan seluruh dunia pada umumnya. CISG 1980 mengikat bagi Negara-negara anggotanya. ${ }^{21} \mathrm{Hal}$ ini berbeda dengan UNIDROIT Principles yang berlaku dengan tetap memperhatikan kebebasan prinsip otonomi masing-masing pihak dalam kontrak, ketentuan hukum kontrak yang ada pada hukum kontrak domestik suatu Negara

19 Indonesia sudah menjadi anggota ke 63 dan telah meratifikasi melalui Peraturan Presiden Republik Indonesia nomor 59 tahun 2008 tentang Pengesahan Statute of International Institute for Unification of Private Law.

20 Lihat http://www.unidroit.org/about-unidroit/membership, diakses tanggal 23 Agustus 2015, 12 November 2014, 09:53 Jumlah Anggota dari UNIDROIT adalah 63 negara.

21 http://www.cisg.law.pace.edu/cisg/countries/cntries.html, diakses 23 Agustus 2015, per tanggal 26 September 2014, UNCITRAL mencatat 83 negara sudah meratifikasi CISG, sampai saat ini Indonesia belum meratifikasi. 
serta prinsip-prinsip yang berlaku pada hukum perdata internasional Negara masing-masing pihak dalam kontrak.

\section{Sistematika Dan Ruang Lingkup}

UNIDROIT Principles terdiri dari mukadimah (preamble) dan 11 (sebelas) bab yang mengatur mengenai General Provision, Formation and Authority of Agent, Validity, Interpretation, Content and Third Party Rights, Performance, Non Performance, Sett off, Assigment of Rights, Transfer of Obligation, Assigment of Contracts, Limitation of Period dan Plurality of Obligors dan Obligees. Sistematika UNIDROIT Principles 2010 berbeda jauh dengan revisi pada 2004 yang terdiri hanya 10 (sepuluh) bab. Perubahan pada UNIDROIT Principles 2010 dengan melakukan penambahan bab terkait dengan Plurality of Obligors dan Obligees serta pemisahan pengaturan Limitation Period ke dalam bab tersendiri.

Berbeda dengan CISG 1980, yang terdiri dari 6 bab, General Provision, Obligation of the seller, Conformity of goods and third party claims, Remedies for breach of contract by the seller, Obligation by the seller, Pasiing of risk, Provisions common to the obligations of the seller and of the buyer, Final Provision. CISG 1980 merupakan pengganti dari the 1964 Uniform Law on The International Sale of Goods. Konvensi ini berlaku untuk kontrak jual-beli barang antara pihak yang mempunyai tempat usaha di Negara yang berlainan. Tujuan utama dari konvensi ini adalah untuk mengurangi perbedaan-perbedaan hukum di antara Negaranegara anggota yang menjadi rintangan bagi perdagangan internasional dan CISG mengkhususkan pada kontrak jual-beli Internasional. ${ }^{22}$ Sementara itu KUHPerdata terdiri dari 4 (empat) buku yang dibagi menjadi buku pertama tentang Orang, buku kedua tentang Kebendaan, buku ketiga mengenai Perikatan dan buku ke empat mengenai Pembuktian dan Kadaluarsa. Khusus mengenai Perjanjian ada dalam buku ke tiga mengenai Perikatan yang terdiri dari 18 (delapan belas) bab yang berisi perikatan pada umumnya, perikatan yang

22 Viktor Purba, Kontrak Jual Beli Barang Internasional (konvensi Vienna 1980), Disertasi Doktor Universitas Indonesia, Jakarta, 2002, hlm. 29. 
dilahirkan dari kontrak atau perjanjian, perikatan yang dilahirkan demi undangundang, hapusnya perikatan, jual beli, tukar menukar, sewa menyewa, perjanjian untuk melakukan pekerjaan, persekutuan, perkumpulan, hibah, penitipan barang, pinjam-pakai, pinjam-meminjam, bunga tetap atau bunga abadi, perjanjian untung-untungan, pemberian kuasa, penanggungan, dan perdamaian.

Ruang lingkup hal-hal yang diatur di dalam KUHPerdata lebih luas dibandingkan dengan UNIDROIT Principles dan CISG 1980. Hal ini dapat dilihat dari UNIDROIT Principles yang hanya mengatur kontrak perdagangan. ${ }^{23}$ Dalam KUHPerdata khususnya mengenai perikatan tidak hanya diatur mengenai jual-beli ataupun perdagangan saja. Buku Ketiga KUHPerdata juga mengatur mengenai perdamaian, sewa menyewa, pinjam meminjam, pinjam pakai, pemberian kuasa dan lainnya.

Selain itu buku Ketiga KUHPerdata tidak memisahkan antara kontrak dagang ataupun kontrak dalam hubungan perdata lainnya. Meskipun demikian, jika ingin dipahami dalam pengertian kontrak dagang sebagai jual beli, maka hal itu ternyata diatur pada Pasal 1457 KUHPerdata ${ }^{24}$ dan yang menyatakan jual-beli sudah terjadi sejak adanya kata sepakat mengenai barang dan harga. ${ }^{25}$ Seperti halnya CISG 1980 yang hanya mengatur tentang jual beli internasional, KUHPerdata mengatur mengenai jual beli dalam Pasal 1457 KUHPerdata, namun tidak memisahkan antara unsur internasional dan nasional.

\section{Keabsahan Suatu Kontrak}

CISG 1980 hanya mengatur proses pembentukan suatu kontrak penjualan beserta hak dan kewajiban penjual dan pembeli yang timbul dari kontrak tersebut.

23 Lihat Preamble dari UNIDROIT Principles 2010 alinea pertama yang menyatakan These Principles set for the general rules for international commercial contracts. (terjemahan bebas penulis, Prinsip-prinsip ini ditetapkan untuk aturan umum kontrak dagang internasional).

24 Lihat Pasal 1457 KUHPerdata: Jual-beli adalah perjanjian dengan mana pihak yang satu mengikatkan dirinya untuk menyerahkan suatu kebendaan dan pihak lain untuk membayar harga yang disetujui.

25 Lihat pasal 1458 KUHPerdata: Jual beli itu dianggap telah terjadi antara kedua belah pihak, seketika setelahnya orang-orang ini mencapai sepakat mengenai kebendaan tersebut dan harganya, meskipun kebendaan itu belum diserahkan, maupun harganya belum dibayar. 
Ini dapat disimpulkan dari bunyi ketentuan Pasal 4 CISG 1980.26 CISG tidak mengatur mengenai keabsahan dari suatu kontrak ataupun ketentuan lain yang dapat digunakan untuk menentukan keabsahan dari suatu kontrak. ${ }^{27}$ Sebagai contoh dikemukakan kasus yang terjadi antara Hungaria sebagai Penjual dengan Austria sebagai pembeli. Kontrak dibuat untuk tahunan periode 1 Februari 1994 hingga 31 Januari 1995 melalui perjanjian Pemasokan. Setelah selesai kontrak tersebut diperpanjang untuk periode 28 Februari 1995 sampai dengan 29 Februari 1996. Namun sebelum kontrak itu dilaksanakan pemerintah mengakhiri kontrak itu dengan alasan kontrak itu tidak sah karena bertentangan dengan hukum nasional Austria. ${ }^{28}$

Bagian I dari CISG yang mengatur mengenai ruang lingkup penerapan dan ketentuan umum (sphere of application and general provisions) menjabarkan ruang lingkup penerapan dan ketentuan umum yang terkait dengan CISG 1980. Salah satu ketentuan umum yang diatur yaitu mengenai keabsahan dari suatu kontrak (validity). CISG 1980 dalam Pasal 4 (a) (terjemahan bebas) menetapkan:

Konvensi ini hanya mengatur pembuatan kontrak perdagangan serta hak dan kewajiban dari penjual dan pembeli yang timbul dari kontrak tersebut. Secara khusus, kecuali sebagaimana dengan tegas dinyatakan lain dalam Konvensi ini, Konvensi tidak mengatur hal-hal berikut ini:

(a) keabsahan kontrak atau setiap ketentuannya atau setiap penggunaannya;

26 Pasal 4 CISG 1980: This convention governs only the formation of the contract of sale and the rights and obligations of the seller and the buyer arising from such a contract. In particular, except as otherwise expressly provided in this convention it is not concerned with : (a) the validity of the contract or any of its provisions or of any usage, (b) the effect which contract may have on the property in the goods sold. (terjemahan bebas Penulis: Konvensi ini hanya mengatur pembuatan kontrak perdagangan serta hak dan kewajiban dari penjual dan pembeli yang timbul dari kontrak tersebut. Secara khusus, kecuali sebagaimana dengan tegas dinyatakan lain dalam Konvensi ini, Konvensi tidak mengatur hal-hal berikut ini: (a) keabsahan kontrak atau setiap ketentuannya atau setiap penggunaannya; (b) dampak yang mungkin ditimbulkan oleh kontrak terhadap hak milik atas barang yang dijual.)

27 Peter Huber, Alastair Mullis, The CISG A new textbook for student and pratitioners, Sellier, european Law Publisher, hlm., 64

28 Lihat hasil putusan dari Mahkamah Agung Austria tanggal 22 Oktober 2001 Business Number 1 Whether 77/01g Source: Legal Information System (RIS) of the Republic of Austria (www.ris.bka.gv.at), http://www.unilex.info/case.cfm?pid=1\&do=case\&id=764\&step=FullText. diakses tanggal 6 september 2015 
Ketentuan pasal 4 (a) secara jelas menyatakan konvensi ini tidak mengatur mengenai syarat keabsahan dari suatu kontrak (validity). Pengecualian ini tentunya mempunyai maksud tersendiri. Alasan pengecualian ini dapat diduga adalah dalam rangka melindungi kepentingan para pihak yang berbeda yang diatur sejalan dengan peraturan perundang-undangan domestik dari masingmasing Negara (para pihak). Lagipula, sudah dapat dipastikan bahwa para pihak lebih memahami hukum Negara masing-masing dibandingkan hukum Negara mitra yang menjadi rekanan bisnisnya. CISG 1980 juga tidak mensyaratkan dengan tegas adanya bentuk formal suatu kontrak. Itu sebabnya CISG 1980 mengakomodir bentuk kontrak secara lisan maupun tertulis sepanjang hal itu dapat dibuktikan oleh para pihak. ${ }^{29}$ Namun demikian, suatu ketentuan hukum kontrak dari masing-masing pihak yang bersifat memaksa tidak dapat disimpangi oleh para pihak. Sebagai contoh, jika hukum kontrak suatu Negara mewajibkan kontrak dibuat dalam bentuk tertulis, maka ketentuan itu bersifat memaksa dan mengikat para pihak. Demikian juga dalam hal suatu kontrak tertulis berisi ketentuan yang menetapkan bahwa perubahan kontrak atau pengakhiran kontrak harus dilakukan secara tertulis, maka keharusan itulah yang mengikat para pihak. Dalam hal para pihak ingin melakukan perubahan ataupun pengakhiran dari suatu perjanjian jual-beli, hal ini dapat dilakukan cukup dengan kesepakatan dari para pihak (by the mere of the parties). ${ }^{30}$

29 Pasal 11 CISG 1980: A contract of sale need not be concluded in or evidenced by writing and it is not subject to any other requirement as to form. It may be proved by any means, including witnesses. (Terjemahan bebas Penulis: Kontrak perdagangan tidak harus disepakati atau dibuktikan secara tertulis dan tidak tunduk kepada setiap persyaratan lain berkaitan dengan bentuknya. Kontrak perdagangan dapat dibuktikan dengan cara apapun, termasuk kesaksian.)

30 Pasal 29 (1) CISG 1980: A contract may modfied or terminated by the mere agreement of the parties (2) A contract in writing which contains a provision requiring any modfication or termination by agreement to be in writing may not be otherwise modfied or terminated by agreement. However, a party may be precluded by his conduct from asserting such a provision to the extent that the other party has relied on that conduct. (terjemahan bebas Penulis: (1) Kontrak dapat diubah atau diakhiri hanya dengan persetujuan para pihak yang terkait. (2) Kontrak tertulis yang memuat ketentuan yang mensyaratkan setiap perubahan atau pengakhiran dilakukan melalui perjanjian tertulis, sebaliknya, tidak dapat diubah atau diakhiri melalui perjanjian. Meskipun demikian, satu pihak dapat dilarang untuk melakukan tindakan 
Hampir sama dengan UNIDROIT Principle yang mengakomodir dan memberikan kebebasan bagi para pihak untuk membuat, mengubah serta mengakhiri kontrak itu dan tidak memerlukan persyaratan atau ketentuan lain. ${ }^{31}$ Keabsahan dari suatu kontrak dikaitkan pada kesepakatan para pihak berdasarkan asas kebebasan berkontrak. UNIDROIT Principles bertujuan memberikan solusi terhadap masalah yang timbul ketika tidak dimungkinkan untuk menggunakan sumber hukum yang relevan dari hukum yang berlaku di suatu Negara. Karena itu, UNIDROIT Principles digunakan sebagai sumber hukum yang dijadikan acuan dalam menafsirkan ketentuan hukum kontrak yang tidak jelas. ${ }^{32}$ Apabila tidak ditemukan aturan yang berlaku dalam hukum yang berlaku dan mengatur kontrak yang dibuat (governing law), maka UNIDROIT Principles dapat digunakan sebagai acuan. Artinya prinsip-prinsip yang ada menjadi instrumen hukum tambahan yang juga dianggap berlaku dan mengikat. Sebabnya ialah karena prinsip-prinsipnya diambil dari kebiasaan dan praktik yang seragam secara internasional. Singkat kata, untuk bagian terbesar UNIDROIT Principles dimaksudkan sebagai seperangkat aturan penyeimbang untuk digunakan di seluruh dunia tanpa memperhatikan tradisi hukum dan kondisi ekonomi politik. Dari segi formal, UNIDROIT Principles ini menghindari penggunaan terminologi khusus yang digunakan dalam sistem hukum tertentu.

UNIDROIT Principles tidak mengatur ketidaksahan kontrak yang timbul dari tidak dimilikinya kemampuan/tidak adanya kewenangan. ${ }^{33}$ Akibatnya, masalah seperti ultra vires, kewenangan lembaga dan lainnya tidak diatur dalam UNIDROIT Principles. Alasan tidak diaturnya adalah adanya kompleksitas yang

dengan tujuan mempertahankan ketentuan tersebut sepanjang pihak lainnya tersebut meyakini tindakan tersebut).

31 Pasal 3.1.2 UNIDROIT Principle: A contract is concluded, modified or terminated by mere agreement of the parties, without any firther requirement. (terjemahan bebas Penulis: Suatu kontrak terbentuk, diubah ataupun diakhiri berdasrkan kesepakatan para pihak dan tidak memerlukan ketentuan lain).

32 Taryana Soenandar, Prinsip-prinsip UNIDROIT sebagai sumber hukum kontrak dan penyelesaian sengketa., Sinar Grafika, Jakarta, hlm., 10.

33 Pasal 3.1.1 UNIDROIT Principles This chapter does not deal with lack of capacity.", International Institute for The Unification of Private Law, International Principles of Commercial Contracts, (Roma: 2010). 
melekat pada masalah status, kewenangan, dan kebijaksanaan publik serta perbedaan yang ekstrem mengenai bagaimana hal-hal tersebut diberlakukan dalam hukum domestik. Alhasil persoalan penetapan kewenangan dan kecakapan diserahkan sepenuhnya pada pengaturan dalam hukum Nasional. ${ }^{34}$ UNIDROIT Principles hanya mengatur keabsahan kontrak berdasarkan aspek persetujuannya saja. Pada dasarnya prinsip ini hanya mengatur mekanisme kesepakatan para pihak berdasarkan kebebasan berkontrak. Maka tidak adanya konsiderasi (pada sistem common law) dari kedua belah pihak dan tidak adanya sebab yang halal (dalam sistem civil law) tidak menghalangi keabsahan kontrak, selama dalam kontrak tersebut terdapat kesepakatan dari para pihak.

Kendati begitu pada bagian akhir UNIDROIT Principles kita temukan pengaturan perihal apa saja yang dapat membuat kesepakatan cacat, yaitu kekeliruan (mistake) baik dalam bentuk kekeliruan dalam fakta maupun kekeliruan dalam hukumnya, ${ }^{35}$ penipuan (fraud), ${ }^{36}$ ancaman (threat), ${ }^{37}$ dan perbedaan besar (gross disparity). ${ }^{38}$ Mengenai kekeliruan (mistake) UNIDROIT Principles $^{39}$ tidak membedakan antara kekeliruan fakta dengan kekeliruan terkait dengan ketentuan hukum yang ada. Secara umum kekeliruan dapat terjadi pada fakta maupun pada ketentuan hukum yang ada. Maksudnya apabila kekeliruan mengenai fakta dan hukum terjadi, hal itu dapat mengakibatkan para pihak tidak lagi bersedia untuk mengikatkan diri pada kontrak. Kekeliruan tersebut haruslah kekeliruan yang serius dan bukan kekeliruan yang dapat dihindari oleh para pihak yang dalam keadaan wajar membaca dan menyimpulkan isi kontrak.

Selanjutnya, gross disparity merupakan pelaksanaan dari prinsip itikad baik (good faith) dan transaksi jujur (fair dealing) serta prinsip keseimbangan dan

\footnotetext{
34 Supra no 32, hlm., 64

35 Lihat Pasal 3.2.1. UNIDROIT Principle

${ }^{36}$ Lihat Pasal 3.2.5. UNIDROIT Principle

${ }^{37}$ Lihat Pasal 3.2.6. UNIDROIT Principle

38 Lihat Pasal 3.2.7. UNIDROIT Principle

39 Pasal 3.2.1. UNDIROIT Principles: Mistake is an erroneous relating to fact or to law existing when contract was concluded (terjemahan bebas Penulis: kekeliruan adalah asumsi yang keliru berkaitan dengan fakta atau hukum yang ada saat kontrak dibentuk)
} 
keadilan. Hal ini dilandasi adanya kenyataan disparitas yang besar di masyarakat. Oleh karena itu diperlukan bentuk aturan yang dapat melindungi pihak yang memiliki posisi yang tidak menguntungkan. ${ }^{40}$ Salah satu pihak dapat membatalkan seluruh atau sebagian ketentuan yang ada pada kontrak, apabila ketentuan-ketentuan pada kontrak itu memberikan keuntungan yang berlebihan secara melawan hukum. Keuntungan yang berlebihan yang dianggap tidak dibenarkan itu disebabkan oleh:41

a. posisi tawar yang tidak seimbang;

b. sifat dan tujuan dari kontrak;

c. faktor-faktor lain, sehingga menimbulkan hak untuk membatalkan atau mengubah kontrak.

Keuntungan berlebihan secara tidak sah itu harus terjadi atau muncul pada saat pembuatan kontrak. Atau setidaknya dengan memperhatikan isi dari ketentuan-ketentuan pada kontrak dapat diduga bahwa salah satu pihak akan mendapatkan keuntungan yang berlebihan. Namun, hal ini tidak dapat dikaitkan dengan risiko yang timbul dari pelaksanaan kontrak itu sendiri. Jika dalam pelaksanaan kontrak itu, salah satu pihak mendapatkan keuntungan yang besar dengan cara tidak melawan hukum, maka hal itu tidak dapat dikatakan telah terjadi perbedaan yang mencolok (gross disparity).

Sebagai perbandingan di dalam KUHPerdata Indonesia, sahnya suatu kontrak ditentukan berdasarkan kata sepakat dari para pihak, kecakapan, suatu hal tertentu dan suatu sebab yang halal. ${ }^{42}$ Dua syarat pertama yaitu kata sepakat dan kecakapan merupakan syarat subjektif. Disebut demikian karena terkait dengan subyek atau pihak dalam kontrak itu. Dua syarat kedua, hal tertentu dan sebab yang halal merupakan syarat obyektif karena hal ini terkait dengan obyek dari perjanjiannya.

\footnotetext{
40 Supra no 32, hlm., 65-66.

41 Id., hlm. 66.

42 Lihat Pasal 1320 KUHPerdata.
} 
Apabila suatu kontrak tidak memenuhi unsur obyektif pada Pasal 1320 KUHPerdata tersebut, kontrak menjadi batal demi hukum. Hal ini ditegaskan pula dalam Putusan Mahkamah Agung RI No.4091 K/PDT/1989 (30 November 1991) yang mempertimbangkan:

Akta pelepasan hak dengan pemberian ganti rugi dinyatakan batal demi hukum karena tidak memenuhi ketentuan unsur obyektif pada Pasal 1320 KUHPerdata, dalam hal ini pihak pelepas hak tidak mempunyai hak sedikitpun untuk menjual, menjaminkan, dan atau memiliki objek perkara sehingga perjanjian pelepasan hak dianggap tidak pernah terjadi.

Unsur sepakat pada syarat perjanjian menurut Pasal 1320 KUHPerdata dimaksudkan bahwa, para pihak yang mengadakan perjanjian harus bersepakat dan setuju mengenai hal-hal yang diperjanjikan, dikehendaki. KUHPerdata sendiri tidak memberikan pengertian ataupun maksud dari kata sepakat. Menurut Herlien Budiono, kata sepakat mencakup pengertian tidak saja untuk mengikatkan diri, tetapi juga berhak atas prestasi yang telah diperjanjikan. Dalam suatu kontrak, masing-masing pihak tidak saja mempunyai kewajiban, akan tetapi berhak juga atas prestasi yang telah diperjanjikan. Suatu kontrak sepihak yang memuat hak dan kewajiban satu pihak untuk mendapatkan/memberikan prestasi, tetap mensyaratkan adanya kata sepakat dari kedua belah pihak. ${ }^{43}$ Sudikno Mertokusumo selanjutnya juga menyatakan bahwa kesepakatan adalah persesuaian pernyataan kehendak antara satu orang atau lebih dengan pihak lainnya. Apa yang harus sesuai adalah pernyataannya, karena kehendak para pihak tidak dapat dilihat/diketahui orang lain. ${ }^{44}$ Sepakat juga tidak akan tercapai jika kesepakatan mengandung, kekhilafan, paksaan dan penipuan. ${ }^{45}$ Suatu kekeliruan dalam membuat suatu kontrak dapat terjadi mengenai jumlah, jenis ataupun kualitas serta harga dari barang yang menjadi obyek perjanjian jual-beli.

43 Herlien Budiono, Ajaran Umum Hukum Perjanjian dan Penerapannya di Bidang Kenotariatan, PT. Citra Aditya Bakti, Bandung, hlm. 73-74.

44 Sudikno Mertokusumo, Rangkuman Kuliah Hukum Perdata pada Salim HS, Perkembangan Hukum Kontrak Innominat di Indonesia, Sinar Grafika, Jakarta, hlm. 12.

45 Lihat Pasal 1321 KUH Perdata: Tiada sepakat yang sah apabila sepakat itu diberikan karena kekhilafan, atau diperolehnya dengan paksaan dan penipuan. 
Dalam hal suatu kesepakatan didasari atau tercapai karena kekerasan atau paksaan serta ancaman, maka hal itu haruslah yang bersifat melanggar hukum, seperti diancam untuk dibunuh, diculik, dianiaya. Suatu ancaman yang tidak bertentangan dengan undang-undang tidak dapat dianggap sebagai kekerasan, yaitu ancaman akan digugat di pengadilan atau akan dilaporkan kepada pihak kepolisian.

Pada UNIDROIT Principles tidak dipermasalahkan mengenai kecakapan atau kewenangan. Sebaliknya, di dalam KUHPerdata, unsur kedua yaitu mengenai kecakapan (capacity) yang merupakan bagian dari unsur subyektif, mempunyai arti yang penting. Tidak terpenuhinya unsur subyektif menyebabkan kontrak itu dapat dibatalkan. Menurut Pasal 1329 KUHPerdata pada dasarnya setiap orang berwenang untuk membuat perikatan kecuali yang dinyatakan tidak cakap untuk hal itu. KUHPerdata mengatur pihak-pihak yang dikatakan tidak cakap untuk membuat suatu perjanjian yaitu anak yang belum dewasa dan orang yang berada di bawah pengampuan. ${ }^{46}$

\section{Dampak Harmonisasi Hukum Kontrak}

Bidang hukum yang penting untuk diperhatikan dalam perdagangan internasional adalah hukum kontrak. Perbedaan pengaturan hukum kontrak (nasional) dalam suatu transaksi perdagangan internasional yang melibatkan pelaku usaha dari dua atau lebih negara yang berbeda tentu akan menimbulkan ketidakpastian hukum. Sebagai contoh, transaksi jual beli internasional yang dilakukan oleh pengusaha Vietnam dengan pengusaha Indonesia akan melibatkan dua sistem hukum (keperdataan) yang sama. Sekalipun kedua sistem hukum dua Negara berbeda ini mencirikan tradisi hukum civil law, tidak berarti bahwa ketentuan mengenai hukum kontrak antara Vietnam dan Indonesia pasti juga sama. Terlebih lagi jika kita berbicara dengan Negara yang memiliki sistem hukum yang berbeda, seperti halnya Singapura dengan tradisi hukum common law dan mempunyai pengaturan yang berbeda dengan hukum kontrak Indonesia yang

${ }^{46}$ Lihat Pasal 1330 KUHPerdata. 
mengikuti tradisi hukum Eropa Kontinental. Perbedaan pengaturan dan juga pemahaman akan hukum kontrak dari mereka yang berasal dari tradisi hukum berbeda tentunya memunculkan potensi konflik.

Untuk itu, maka diperlukan harmonisasi hukum kontrak, satu dan lain dalam rangka menghilangkan hambatan yang berasal dari pengaturan hukum kontrak berbeda pada transaksi perdagangan internasional. Tujuannya adalah mendorong kegiatan ekonomi dalam pasar regional ASEAN. Harmonisasi hukum nasional pada aras regional dan hukum kontrak pada khususnya, akan memberikan perlindungan yang efektif untuk para pelaku bisnis yang berasal dari Negara berbeda. Perlindungan itu setidaknya akan muncul ketika risiko terjadinya konflik dengan sengketa akibat dari ketidaktahuan akan aturan hukum kontrak dari rekan bisnis yang berasal dari Negara yang berbeda dapat diminimalisir.

Upaya harmonisasi hukum kontrak harus diikuti dengan penyesuaian dalam hukum nasional masing-masing Negara. Harmonisasi dapat menjadi aset budaya baru, nilai baru yang sangat besar bagi masing-masing Negara dan khususnya bagi negara-negara ASEAN. Pengalaman yang diperoleh dari melaksanakan harmonisasi di tingkat nasional dan regional akan turut membantu dan mendukung integrasi ekonomi antara negara-negara anggota ASEAN. ${ }^{47}$

Indonesia sebagai salah satu Negara pendiri dari ASEAN memiliki peran penting baik secara ekonomi dan politik di wilayah regional ASEAN. Peran penting ini tentunya harus dapat dimanfaatkan oleh Indonesia sebagai penggerak dalam rangka harmonisasi hukum kontrak. Ikhtiar ini dapat dimulai dengan mencermati ketentuan-ketentuan yang ada di dalam KUHPerdata terkait perjanjian, serta ketentuan serupa di dalam UNIDROIT Principles dan CISG 1980. Keduanya dipilih sebagai referensi karena penerimaannya yang luas sebagai acuan dalam pembuatan kontrak perdagangan internasional.

Di samping itu, sejak 1966 Perserikatan Bangsa-Bangsa (PBB) dengan

47 Mochtar Kusumaatmaja, Seminar on Legal Aspect of Regional Cooperation: harmonization of Laws in the Region. Asian Development Bank, http://www.adb.org/document/conference/ seminar_cooperation/coop2110.asp. 
membentuk United Nations Commisions on International Trade Law (UNCITRAL) menyatakan bahwa hukum dan kebiasaan yang berlaku dalam transaksi perdagangan internasional dapat kita temukan dalam tiga bentuk yaitu: 48

a) Konvensi-konvensi Internasional yang ditandatangani oleh Negara-negara;

b) Model Hukum (model laws) yang dibuat oleh organisasi-organsisasi internasional ;

c) Kebiasaan-kebiasaan atau praktek Negara-negara yang digunakan dalam perjanjian dagang.

Beranjak dari itu, terbuka peluang bagi Indonesia untuk mencermati konvensi-konvensi Internasional, model hukum serta kebiasaan-kebiasaan dari Negara-negara lain dalam melakukan kontrak dagang internasional. Kesemua itu dilakukan dalam rangka pembaharuan hukum kontrak Indonesia. Apa yang perlu menjadi tujuan adalah menemukan keseragaman prinsip. Keseragaman prinsip dalam hukum kontrak akan membuat pelaksanaan dari transaksi perdagangan internasional menjadi lebih efektif.

Mengganti ketentuan-ketentuan tentang perjanjian di dalam KUHPerdata tentunya tidak mudah. Hal ini terbukti dengan banyaknya RUU yang terkait dengan perjanjian yang sampai sekarang belum berhasil diundangkan. Namun bersikap pasif dan menunggu juga bukan sikap bijak. Indonesia harus mengambil sikap dan segera melakukan pembaharuan hukum kontrak, yakni dengan tujuan mendukung transaksi perdagangan internasional secara umum maupun khusus di wilayah ASEAN.

Satu hal yang dapat dilakukan adalah segera meratifikasi CISG 1980 terutama apabila dikaitkan dengan momentum Masyarakat ASEAN (ASEAN Community). Terhitung sejak tanggal 26 September 2014, sudah 83 Negara yang telah meratifikasi CISG 1980.49 Singapura merupakan satu-satunya Negara ASEAN

48 John H Jackson, William J. Davey, Second Edition, Amercan Book Series, West Publishing Co, St. Paul 1986, hlm. 36. Dalam Artikel Ietje K. Andries, Unifikasi dan Kodifikasi Hukum Perdagangan Internasional Khususnya Jual Beli Barng Secara Internasional, Seri Dasar Hukum Ekonomi 7, Jual Beli Barang Secara Internasional, ELIPS, 1998, hlm. 31.

49 http://www.cisg.law.pace.edu/cisg/countries/cntries.html., 8 September 2015. 
yang sudah meratifikasi CISG 1980 terhitung sejak 1 Maret 1996..$^{50}$ Ratifikasi CISG 1980 juga merupakan salah satu bentuk atau upaya untuk melakukan harmonisasi hukum kontrak, khususnya mengenai jual-beli barang secara internasional. Ini akan berguna terutama bagi Negara-negara yang sudah meratifikasi CISG 1980 karena mereka mempunya acuan yang sama ketika mengatur transaksi jual beli di antara Negara-negara pihak.

Adapun alasan-alasan lain perlu diratifikasinya CISG 1980, antara lain:51

1) Dengan makin terbukanya ekonomi Indonesia sebagai dampak dari globalisasi, akan semakin banyak pula transaksi perdagangan yang dilakukan oleh warga negara Indonesia dengan pihak asing. Untuk itu diperlukan perangkat kaidahkaidah hukum yang mendukung perdagangan internasional.

2) Konvensi tersebut merupakan konvensi yang menyeragamkan kaidah-kaidah hukum perdagangan internasional di bidang Kontrak Jual Beli Barang Internasional yang dipersiapkan oleh UNCITRAL. Konvensi tersebut sudah menjadi hukum positif yang berlaku sejak 1 Januari 1988. Diantara peserta konvensi tersebut terdapat pula peserta dari negara berkembang.

Sedangkan dalam rangka mendukung transaksi perdagangan internasional yang dilakukan oleh warga negara Indonesia, Indonesia perlu menjadi peserta Konvensi tersebut dengan alasan-alasan khusus: ${ }^{52}$

a. Konvensi tersebut memuat asas-asas yang terdapat dalam hukum kontrak pada umumnya dan asas-asas tersebut tidak bertentangan dengan KUHPerdata;

b. Pada saat Indonesia telah menjadi peserta Konvensi, Indonesia dapat menyatakan deklarasi, yaitu yang didasarkan pada ketentuan Pasal 92 (1), Pasal 93 (1), Pasal 94, Pasal 95 dan Pasal 96. Dengan adanya kemungkinan untuk mengadakan deklarasi, kaidah-kaidah hukum Kontrak Jual Beli

50 Lihat http://wtocenter.vn/vien-convention/members-cisg-0., 8 September 2015

51 Naskah Akademik tentang Ratifikasi Konvensi PBB Mengenai Kontrak Jual Beli Barang Internasional, Badan Pembinaan Hukum Nasional, Jakarta, 2013, hlm., 8.

52 Id., hlm.. 9. 
Internasional tetap dapat dijadikan dasar atau sebaliknya tidak dipakai atau diubah oleh para pihak dalam hubungan Kontrak Jual Beli Barang Internasional. Dalam hal ini, asas kebebasan berkontak tetap dihormati.

c. Dengan meratifikasi Konvensi tersebut berarti Indonesia berusaha mengadakan harmonisasi hukum Kontrak Jual Beli Nasional dengan Kontrak Jual Beli Internasional dan sekaligus memperbaharui hukum kontral nasional. Secara umum, dalam rangka perdagangan internasional tentu diperlukan aturan seragam yang berlaku secara umum (uniforms rules), 53 otonom, dan dapat diterima oleh semua Negara.

Bagaimana dengan hukum kontrak Indonesia? Perlu dilakukan kajian perihal apa saja yang sudah tidak sesuai dengan perkembangan berbagai kegiatan bisnis dewasa ini dan apa yang dapat dilakukan dalam rangka perbaikan serta penyempurnaannya. Tujuan akhirnya, Indonesia memiliki hukum kontrak yang modern yang dapat mengakomodasi kegiatan bisnis dewasa ini. Perbaikan dan penyempurnaan hukum kontrak Indonesia mutlak harus dilakukan mengingat bahwa di era global dewasa ini sistem hukum kontrak Indonesia sudah pasti akan bersinggungan dengan pelbagai sistem hukum lainnya.

Dapat dicermati bahwa ketentuan mengenai keabsahaan kontrak di atur secara berbeda antara KUHPerdata dengan UNIDROIT Principles serta CISG 1980. Di dalam ketentuan Pasal 1320 KUHPerdata keabsahan suatu kontrak dikaitkan pada empat syarat: kesepakatan, kecakapan, obyek tertentu dan sebab yang halal. Sebaliknya seperti sudah dijelaskan sebelumnya UNIDROIT Principles menentukan bahwa keabsahaan suatu kontrak diserahkan kepada kesepakatan masing-masing pihak. CISG 1980 tidak menentukan secara jelas syarat keabsahan kontrak. Apa yang dilakukannya adalah menyerahkan persoalan penentuan keabsahan pada hukum nasional dari masing-masing Negara.

53 Menurut pendapat Schmitthof uniforms rules yang otonom dan dapat diterima oleh semua negara yang bersifat universal disebut sebagai New Lex Mercatoria. CM. Schmittoff, The Unification of International Trade, dalam Chia -Jui-Cheng, Select Essays on International Trade Law, Martinus Nijhoff Publisher, 1988, hlm., 221. 


\section{Penutup}

Harmonisasi hukum kontrak merupakan jalan tengah yang dapat ditempuh dalam rangka pembaharuan hukum kontrak Indonesia. Dengan harmonisasi berarti tidak memaksakan suatu ketentuan atau aturan hukum kontrak dari Negara untuk berlaku pada Negara lain, demikian juga sebaliknya. Selain itu, melalui harmonisasi hukum kontrak, secara khusus Indonesia tetap dapat melakukan pembaharuan terhadap hukum kontrak Indonesia.

Pada saat sama, ketika Indonesia menghadapi perkembangan transaksi atau perdagangan modern, maka perlu disediakan hukum kontrak yang sejalan dengan standar yang ditetapkan UNCITRAL Principles maupun CISG 1980. Di samping itu perlu diperhatikan kemajuan teknologi informasi yang jelas besar pengaruhnya terhadap variasi bentuk-bentuk transaksi perdagangan internasional.

Selain itu satu hal yanga perlu diperhatikan ialah ketentuan tentang syaratsyarat absahnya suatu perjanjian. Ketentuan dalam Hukum Kontrak Indonesia (KUHPerdata, khususnya pasal 1320) kiranya masih layak dipertahankan dan diperjuangkan agar menjadi acuan bersama ketika membuat kontrak-kontrak bisnis atau transaksi internasional. Asas yang termuat di dalamnya, kebebasan berkontrak, kiranya tetap menjamin kebebasan bagi para pihak dalam menentukan mekanisme atau ketentuan untuk keabsahan suatu kontrak.

\section{Daftar Pustaka}

\section{Buku:}

CM. Schmittoff, The Unification of International Trade, dalam Chia -Jui-Cheng. Select Essays on International Trade Law, Martinus Nijhoff Publisher, 1988. Herlien Budiono, Ajaran Umum Hukum Perjanjian dan Penerapannya di Bidang Kenotariatan, PT. Citra Aditya Bakti, Bandung, 2011.

Huala Adolf, Dasar-dasar Hukum Kontrak Internasional, cet. ke-2, Refika Aditama, Bandung, 2008.

John H Jackson, William J. Davey, Second Edition, American Book Series, West

Publishing Co, St. Paul 1986. 
Peter Huber, Alastair Mullis, The CISG A new textbook for student and pratitioners, Sellier, european Law Publisher, 2007.

Sudikno Mertokusumo, Rangkuman Kuliah Hukum Perdata pada Salim HS, Perkembangan Hukum Kontrak Innominat di Indonesia, Sinar Grafika, Jakarta,

Sunaryati Hartono, Setiawan, Taryana Sunandar, The Indonesia Law on Contracts, Institute of Developing Economies (IDE JETRO), Japan, 2001.

Sudargo Gautama, Kontrak Dagang Internasional, Alumni, Bandung, 1976.

Sudargo Gautama, Hukum Perdata dan Dagang Internasional, Alumni, Bandung, 1980

Taryana Soenandar, Prinsip-prinsip UNIDROIT sebagai sumber hukum kontrak dan penyelesaian sengketa, Sinar Grafika, Jakarta, 2004.

Wilis L.M Reese, "The Law Governing International Contracts," dalam: Hans Smit, et.al., International Contracts, New York: Mathew Bender, 1981.

\section{Disertasi/Jurnal:}

Ietje K. Andries, Unifikasi dan Kodifikasi Hukum Perdagangan Internasional Khususnya Jual Beli Barng Secara Internasional, Seri Dasar Hukum Ekonomi 7, Jual Beli Barang Secara Internasional, ELIPS 1998.

Naskah Akademik tentang Ratifikasi Konvensi PBB Mengenai Kontrak Jual Beli Barang Internasional, Badan Pembinaan Hukum Nasional, Jakarta, 2013.

Viktor Purba, Kontrak Jual Beli Barang Internasional (konvensi Vienna 1980), Disertasi Doktor Universitas Indonesia, Jakarta, 2002.

\section{Internet}

http://www.cisg.law.pace.edu/cisg/countries/cntries.html., 8 September 2015. http://wtocenter.vn/vien-convention/members-cisg-0., 8 September 2015.

Mochtar Kusumaatmaja, Seminar on Legal Aspect of Regional Cooperation: harmonization of Laws in the Region. Asian Development Bank, http://www.adb.org/document/conference/seminar_cooperation/coop21 10.asp.

http://www.unilex.info/case.cfm?pid=1\&do=case \&id=764\&step=FullText. diakses tanggal 6 september 2015

http://www.unidroit.org/about-unidroit/membership, 23 Agustus 2015, Last Updated: Wednesday, 12 November 2014 09:53 Jumlah Anggota dari UNIDROIT adalah 63 negara.

http://www.cisg.law.pace.edu/cisg/countries/cntries.html, 23 Agustus 2015. 